\title{
New rules in Britain make it harder for older scientists to use animals
}

London. The ability of older scientists in Britain to carry out research using animals has been greatly restricted under a new version of the rules governing such research.

The changes shorten the length of a project licence held by a researcher over the age of 65 and effectively prevent anyone older than 70 from holding a project licence outright. Personal licences, which allow researchers to work with live animals and are usually reviewed every five years, will have to be reviewed annually for those over 70 .

The changes are a response to the Feldberg case (see Nature 345, 190; 1990) in which the work of 89-year-old Wilhelm Feldberg, then of the Medical Research Council's National Institute for Medical Research, was publicized by the national press. Feldberg was studying the effect of heat on blood sugar levels in rabbits. An inquiry found that Feldberg had breached the Animals (Scientific Procedures) Act of 1986; the incident showed how it was possible for an eminent retired scientist to drift outside the support and control structures set up by the act.

The media exposure and the intention of the act to foster openness led the Animals Procedures Committee, the independent statutory body which oversees the legislation and which comes under the Home Office, to alter the rules for retired scientists. Although the act does not allow researchers filmed by animal rights activists and then

of a certain age to be refused a project licence, the committee has adopted administrative changes that will make it very difficult for a researcher over 70 to hold one. Under the new rules, researchers over $65 \mathrm{can}$ obtain or renew licences only up to the time they are 70 .

The easiest solution for researchers caught in this age trap is to have a younger colleague hold the project licence, which should theoretically bring the work back inside the scrutiny of the act.

It is unlikely that these new rules would pass muster in the United States, where discrimination is prohibited on the basis of age in hiring, firing and assigning of duties. Only work that affects public safety, such as firefighting, is exempt. Because animal research has no such impact, says Charles Sabatino, assistant director of the American Bar Association's Commission on Legal Problems of the Elderly, the British policy would probably be illegal in the United States. "It sounds more like a problem with people going off and being independent than with being older," Sabatino says about the new rule.

Although members of the committee concede that only time will tell if the changes are discriminatory, they were felt to be necessary. Not only did the Feldberg case make clear a weakness in the legislation, but it also showed the price of getting caught out.

\section{Worthy proposals get second life}

London. A publishing venture begun this week tells British companies about research proposals that, although highly rated, have failed to win funding from the Science and Engineering Research Council (SERC). But scientists whose work is in the first edition of Hydro Oakland's Research Bulletin would prefer SERC to fund more of the most worthy projects rather than simply to pass them along to industry.

Under the scheme, SERC will give $\mathrm{Hy}$ dro Oakland the abstracts of the proposal and the name of the principal researcher who submitted it at the end of each round of grants. The size of the request will remain confidential, however, and researchers whose proposals are listed will be allowed to resubmit their ideas to SERC.

A pilot issue containing around 140 entries in chemistry and process engineering was published this week and will be given free to interested companies. Once established, the bulletins are expected to support themselves through subscriptions, with Oakland needing 200 to break even. SERC receives no money for the information it supplies. The idea and funding for the project comes from the British arm of Norsk Hydro, Norway's largest industrial company.

The difficulty in getting money for even the most worthy proposals frustrates many British researchers, and the majority of those with entries in the first bulletin welcome the extra exposure. Although on average 70 per cent of alpha-rated proposals are funded, this percentage varies considerably according to discipline. Last year, for example, 90 per cent of the alpha-rated proposals in process engineering were funded but only 22 per cent in chemistry.

However, the prospects for funding are sufficiently poor that most researchers believe they routinely explore every avenue for industrial collaboration through industrial liaison offices or personal networks. Although SERC is supposed to ensure that university research is exploited by industry, most researchers do not see that as its most important function.

Ian Mundell
The annual report of the Animal Procedures Committee also expresses concern over the number of infringements that occur because researchers fail to understand the requirements of the act. As a result, the committee has decided to make formal training a prerequisite before researchers can apply for licences. This change is expected to be implemented by the autumn of 1993 for personal licences and one year later for project licences. The training will cover general matters contained in the act, such as assessing the benefit gained for suffering involved in an experiment and the importance of alternatives to experimental animals, plus the proper conduct of the specific procedures that the licence holder will be doing.

Ian Mundell

\section{US rejects French request to reopen AIDS patent deal}

Washington \& Paris. The long-running battle over the joint US-French patent for the AIDS blood test reached an official stalemate last week when US officials blocked a request by their French counterparts for an increased share of the patent royalties.

Speaking at the biannual meeting of the foundation that administers the annual royalties, officials from the Institut Pasteur proposed a change in the agreement to give France all the royalties now divided equally between the two countries (the majority of the $\$ 8$ million earned annually from the patent) on the grounds that the French deserve most of the credit for discovering the virus. But the four US officials on the eightmember foundation, including Robert Gallo, who is credited in the agreement as the codiscoverer of the virus, and Bernadine Healy, the director of the US National Institutes of Health, voted against the proposal and then walked out. Six votes are needed before any change can be made.

Raymond Dedonder, a member of the French delegation, says he was not surprised; at a previous meeting between the French ambassador and Louis Sullivan, the director of the US Department of Health and Human Services (HHS), Sullivan had warned the French that there "was nothing to consider". Earlier this year, HHS commissioned an independent legal review which found no merit to the French claims.

Dedonder said that no further attempt to reopen the issue would be made until after the US elections in November.

Christopher Anderson \& Declan Butler 